\title{
Article 6. Access to Genetic Resources
}

1. In the exercise of sovereign rights over natural resources, and subject to domestic access and benefit-sharing legislation or regulatory requirements, access to genetic resources for their utilization shall be subject to the prior informed consent of the Party providing such resources that is the country of origin of such resources or a Party that has acquired the genetic resources in accordance with the Convention, unless otherwise determined by that Party.

2. In accordance with domestic law, each Party shall take measures, as appropriate, with the aim of ensuring that the prior informed consent or approval and involvement of indigenous and local communities is obtained for access to genetic resources where they have the established right to grant access to such resources.

3. Pursuant to paragraph 1 above, each Party requiring prior informed consent shall take the necessary legislative, administrative or policy measures, as appropriate, to:

(a) Provide for legal certainty, clarity and transparency of their domestic access and benefit-sharing legislation or regulatory requirements;

(b) Provide for fair and non-arbitrary rules and procedures on accessing genetic resources;

(c) Provide information on how to apply for prior informed consent;

(d) Provide for a clear and transparent written decision by a competent national authority, in a cost-effective manner and within a reasonable period of time;

(e) Provide for the issuance at the time of access of a permit or its equivalent as evidence of the decision to grant prior informed consent and of the establishment of mutually agreed terms, and notify the Access and Benefit-sharing Clearing-House accordingly;

(f) Where applicable, and subject to domestic legislation, set out criteria and/or processes for obtaining prior informed consent or approval and involvement of indigenous and local communities for access to genetic resources; and

(g) Establish clear rules and procedures for requiring and establishing mutually agreed terms. Such terms shall be set out in writing and may include, inter alia: 
(i) A dispute settlement clause;

(ii) Terms on benefit-sharing, including in relation to intellectual property rights;

(iii) Terms on subsequent third-party use, if any; and

(iv) Terms on changes of intent, where applicable.

\section{Overview}

Access to genetic resources is one of the main pillars of the Nagoya Protocol and is considered to be one of the preconditions for the sharing of benefits arising from the utilization of genetic resources. This is recognized in the Protocol's preamble, which points to the 'linkage' between access to genetic resources and benefit-sharing. ${ }^{1}$ Concluded following intense negotiations, the Protocol's provisions on access aim to build the foundation for the cooperation between provider and user countries that will lead to benefit-sharing. These provisions represent the compromise between developed countries that considered themselves as predominantly user countries, which prioritized efficiency in access-related decision-making and legal certainty, in order to avoid hampering research on genetic resources; and developing countries considering themselves as predominantly provider countries, which called for benefitsharing as a self-standing obligation of result for user countries, irrespective of provider countries' regulatory requirements on access. ${ }^{2}$

The Protocol's provisions on access build on the foundational principle enshrined in the $\mathrm{CBD}^{3}$ that sovereign rights over genetic resources are the basis for requiring PIC and establishing MAT. At the same time, Article 6 goes significantly beyond the СвD in three respects. First, it elaborates in greater detail the rights and obligations of Parties in regulating access to genetic resources, aiming to address the enforcement challenges resulting from the transnational component of the ABS transactions. ${ }^{4}$ Second, it promotes best practice in contractual drafting, by providing for clauses that could be negotiated as part

1 Nagoya Protocol 8th preambular recital. See discussion in this commentary on Article 1, section 2.

2 Cariño et al., Nagoya Protocol, op. cit., 57-59.

3 СвD Article 15. Glowka and Normand, "The Nagoya Protocol on Access and Benefit-sharing," op. cit., 29; Greiber et al., Explanatory Guide, op. cit., 94.

4 Young, “An International Cooperation Perspective," op. cit., 453; see also Introduction to this commentary, section 1 . 
of MAT. ${ }^{5}$ Third, it addresses, for the first time in a legally-binding international treaty, ${ }^{6}$ the issue of access to genetic resources held by indigenous and local communities.

Following a brief discussion of the background to Article 6, with reference to the CBD provisions and the Bonn Guidelines, the following sections will focus on each of the components of Article 6, namely: the inter-State obligations related to access to genetic resources; ${ }^{7}$ the obligations related to genetic resources held by indigenous and local communities; ${ }^{8}$ the access standards that will inform the development of domestic ABs frameworks; the minimum procedural requirements for PIC; and the minimum requirements for MAT. ${ }^{9}$

\section{$2 \quad$ Background}

By clarifying that the principle of national sovereignty over natural resources also applies to genetic resources, ${ }^{10}$ and by establishing the obligation for fair and equitable benefit-sharing, the свр introduced key rules on access to genetic resources: the authority of national governments to authorize access to genetic resources under their jurisdiction as part of States' sovereign rights over their natural resources; ${ }^{11}$ the general requirement of PIC for access, unless otherwise determined by the provider Party; ${ }^{12}$ and establishment of MAT in cases access is granted..$^{13}$ These provisions are coupled by the свр benefitsharing obligation, ${ }^{14}$ which applies only to genetic resources provided by Parties that are countries of origin or that have acquired them in accordance with the Convention. ${ }^{15}$

Early attempts to implement these Свр provisions and develop domestic ABS frameworks revealed lack of conceptual clarity about ABS transactions and corresponding legal challenges. These related, for instance, to the frequently

$5 \quad$ Glowka and Normand, “The Nagoya Protocol on Access and Benefit-sharing," op. cit., 30.

6 Ibid., 40.

7 Based on a combined reading of Nagoya Protocol Article 6(1) and the chapeau of Article 6(3).

$8 \quad$ Nagoya Protocol Article 6(2).

$9 \quad$ The latter three are covered by Nagoya Protocol Article 6(3).

$10 \quad$ See Introduction to this commentary, section 1.3.

11 CBD Article 15(1).

12 СвD Article 15(5).

13 СвD Article 15(4).

14 As set out in CBD Article 15(7). See this commentary on Article 5.

15 СвD Article 15(3). See discussion in Introduction to this commentary, section 1.3. 
unclear status of the ownership over genetic resources at the domestic level, resulting in lack of clarity on who was responsible to grant PIC. ${ }^{16}$ In addition, early ABS laws tended to focus mostly on the safeguarding of Parties' sovereign rights to genetic resources in order to secure benefit-sharing, including through permitting and oversight systems, rather than on the efficiency of access-related processes. ${ }^{17}$ This resulted in practical challenges, stemming from the lack of standardized access procedures, as well as the lack of capacity to negotiate benefit-sharing agreements. ${ }^{18}$

Researchers and companies have frequently reported that they avoid jurisdictions with unclear ABs legal frameworks and prefer operating in provider countries where they managed to create predictable working relationships. ${ }^{19}$ However, even countries with supposedly simple access systems have not been significantly more successful in attracting researchers and companies. ${ }^{20}$ Overall what seemed to be lacking was confidence in functioning ABs frameworks as tools for the generation of benefits and support of biodiversity-based research. In addition, ex situ collections in non-СвD parties continued providing genetic material without having to adhere to the $\mathrm{CBD}$ requirements. ${ }^{21}$

This reality, which reflected the legal and practical challenges to develop and implement domestic ABs legislation, did not change significantly after the adoption of the Bonn Guidelines, which represented a first attempt to operationalize the provisions of CBD Article 15, ${ }^{22}$ and constituted the background to the negotiations of Article 6 of the Nagoya Protocol.

16 E.g., Cabrera Medaglia, "The Implementation of the Nagoya Protocol," op. cit., 332 and 357.

17 Young, “An International Cooperation Perspective," op. cit., 453.

18 See свD Secretariat, Access and Benefit-Sharing in Practice: Trends in Partnerships Across Sectors. CBD Technical Series No. 38 (Montreal: CBD Secretariat, 2008); FAO, Framework Study on Food Security and Access and Benefit-Sharing for Genetic Resources for Food and Agriculture (FAO, 2009), accessed 30 November 2013, <ftp://ftp.fao.org/docrep/ fao/meeting/017/ak526e.pdf>; and Jorge Cabrera Medaglia and Christian Silva López, Addressing the Problems of Access: Protecting Sources, While Giving Users Certainty (Gland: IUCN, 2007).

19 СвD Secretariat, Access and Benefit-Sharing in Practice, op. cit., 25.

20 Cabrera Medaglia and Silva López, Addressing the Problems of Access, op. cit., 1.

21 Notably collections in the Us, which is not a Party to the CBD. See FAO The Second Report on the State of the World Plant Genetic Resources for Food and Agriculture (Rome: FAO, 2010), chapter 3.

22 See Introduction to this commentary, section 2. 
The term 'access to genetic resources' is not defined in the CBD or the Nagoya Protocol. ${ }^{23}$ Under the Protocol, it can be argued that in light of the definition of 'utilization of genetic resources' (which itself does not include reference to 'access'), ${ }^{24}$ and considering the wording of Article 6(1) ('access for their utilization'), access may constitute the beginning of the conduct aimed at research and development in the jurisdiction of one Party on the genetic or biochemical composition of genetic resources that are provided by another Party. In addition, taking into account the CBD definition of 'country providing genetic resources, ${ }^{25}$ it can be inferred that genetic resources supplied by a Party to the Nagoya Protocol may originate from both in situ or ex situ sources. In practice, therefore, 'access' can be achieved through different activities in the jurisdiction of the Party providing genetic resources, including by: collecting biological material in the wild; obtaining samples of genetic resources or biochemicals from genebanks, ${ }^{26}$ research institutions or the private sector; or, arguably, obtaining digitalized information about genetic resources and their genetic or biochemical composition. ${ }^{27}$ Against all these possible scenarios, a definition or clarification of the term 'access' in domestic ABS frameworks, possibly following a decision by the Protocol's governing body, ${ }^{28}$ would likely assist in promoting common understanding among Parties and thus legal certainty. It would also facilitate the issuance of domestic permits, which provide

23 For a discussion on this term in relation to Article 15 свD see Glowka, Burhenne-Guilmin and Synge, Guide to the Convention on Biological Diversity, op. cit., 79.

24 See discussion of the relevance of utilization, rather than 'access', for the triggering of the benefit-sharing obligation in this commentary on Article 5, section 2.

25 СвD Article 2, defines the term as 'the country supplying genetic resources collected from in situ sources, including populations of both wild and domesticated species, or taken from ex situ sources, which may or may not have originated in that country.' In addition, according to $\mathrm{CBD}$ Article 15(3), in case the provider country is not the country of origin, the access-related provisions apply if that Party has acquired the genetic resources in accordance with the Convention. See Tvedt and Young, Beyond Access, op. cit., 14; Cariño et al., Nagoya Protocol, op. cit., 63. See also this commentary on Article 5, section 2.

26 Cariño et al., Nagoya Protocol, op. cit., 63.

27 See this commentary on Article 2, section 2.1.1. Margo A. Bagley and Arti K. Rai, The Nagoya Protocol and Synthetic Biology Research: A Look at the Potential Impacts (Washington DC: Wilson Centre, 2013), accessed 30 November 2013, <www.wilsoncenter.org/publication/ the-nagoya-protocol-and-synthetic-biology-research-look-the-potential-impacts $>$. Article 26(4)(a). See this commentary on Article 26, section 2. 
the basis for the internationally recognized certificates of compliance, ${ }^{29}$ that is to occur 'at the time of access.'

The following sub-sections will first discuss the notion of national sovereignty over genetic resources and the Protocol's obligation to develop domestic measures on access - based on a combined reading of Article 6(1) and 6(3), and then the concept of State PIC concerning access to genetic resources.

\subsection{National Sovereignty over Genetic Resources and Domestic Measures on Access}

Based on the reaffirmation of the principle of national sovereignty over natural resources, ${ }^{30}$ Parties have the authority to regulate access to genetic resources and require PIC as the key precondition for access, unless they determine otherwise, subject to domestic ABs legislation or regulatory requirements. ${ }^{31}$ The latter reference is elaborated upon in Article 6(3), which lists, inter alia, a series of standards and minimum requirements for the development of legislative, administrative or policy measures of the provider country regulating access to its genetic resources. The combined reading of the two provisions, however, may arguably give rise to differing interpretations. ${ }^{32}$ Article 6(1) clearly indicates that access to genetic resources is subject to the provider Party's PIC, unless that Party specifically determines that it does not require PIC. Article 6(3) calls on Parties 'requiring PIC' to take the necessary legislative, administrative or policy measures satisfying a series of standards and minimum requirements. Article 6(3) may thus be interpreted so as to imply that the PIC requirement must be explicitly spelt out in domestic measures. Such an interpretation could lead to a practical problem when a Party is silent with regard to its access requirements - i.e., it has not (yet) regulated access in any way nor it has expressly waived its right to PIC - and a user accesses its genetic resources assuming that no PIC is required. In this case, giving priority to the wording of one provision of Article 6 over the other has significant consequences. Is it the user's responsibility to confirm whether PIC is required, in the absence

29 Nagoya Protocol Articles 6(3)(e) and 17(2). See this commentary on Article 17, section 3.

$30 \quad$ Nagoya Protocol Article 6(1).

31 In line with свD Article 15(1), which reads: 'Recognizing the sovereign rights of States over their natural resources, the authority to determine access to genetic resources rests with the national governments and is subject to national legislation,' emphasis added; and СвD Article 15(5), which reads: 'Access to genetic resources shall be subject to prior informed consent of the Contracting Party providing such resources, unless otherwise determined by the Party.'

We are grateful to Tomme Young for drawing our attention to this point. 
of any indication from the provider country, to respect Article 6(1)? Or is it the responsibility of the provider country to set up its regulatory framework, based on a reading of Article 6(3) creating an obligation for Parties to actively exercise their right to require PIC through the establishment of a domestic ABS framework ${ }^{33}$ The former interpretation seems to be supported by the fact that Article 6(3) is expressly subordinated to Article 6(1). ${ }^{34}$ It is also supported by the wording of Article 6(1), which indicates that a Party should make an explicit decision against requiring PIC. ${ }^{35}$ Furthermore, even if the mandatory wording of Article 6(3) indicates an obligation for countries requiring PIC to regulate access to genetic resources at the domestic level ('shall'), failure to do so could possibly qualify as an instance of non-compliance with the Protocol provisions ${ }^{36}$ rather than leading to the deprivation of the Party's right to PIC, which is protected in mandatory terms under Article 6(1) and is a fundamental expression of national sovereignty. That being said, lack of domestic measures on PIC could make it very difficult for the compliance provisions of the Protocol to apply. ${ }^{37}$ Provider countries, therefore, are well advised to develop their domestic ABs frameworks to take full advantage of the Protocol provisions fostering international cooperation, particularly with regard to compliance.

Against this background, users will therefore be well advised to take a cautious approach in cases in which a Party's domestic framework is silent on access to genetic resources, and as a default position assume that PIC is required. ${ }^{38}$ This is already reflected in what is currently considered best practice for user groups: users confirm this with the CBD national focal point of the provider country even in cases where PIC has been specifically waived. ${ }^{39}$

33 See Singh Nijar, The Nagoya Protocol on ABs: An Analysis, op. cit., 16; and Buck and Hamilton, "Nagoya Protocol," op. cit., 51.

34 Note that Nagoya Protocol Article 6(3) starts with the expression 'Pursuant to paragraph 1.

35 As Nagoya Protocol Article 6(1) specifically states 'unless otherwise determined by that Party.' See Greiber et al., Explanatory Guide, op. cit., 96.

36 See this commentary on Article 30.

37 See this commentary on Articles 15-16. Similar concerns about enforceability arose in the context of the СвD: Glowka, Burhenne-Guilmin and Synge, Guide to the Convention on Biological Diversity, op. cit.

38 See also reference to foreign investors' due diligence in this regard in this commentary on Article 4, section 2.1.

39 Greiber et al., Explanatory Guide, op. cit., 96, citing "Access and Benefit-Sharing ABs," Ornamental Aquatic Trade Association (2010), accessed 30 November 2013, $<$ www.ornamental-fish-int.org/uploads/c2/c8/c2c896efd06e24d26710d8b90a40d478/ ABS.pdf>. 
Developing a comprehensive domestic ABs framework would protect first and foremost the rights of the provider country, as well as facilitate implementation of, and compliance with, other provisions of the Protocol. ${ }^{40}$ To that end, Parties enjoy a wide margin of discretion in developing their regulatory approach to ABS under Article 6(3), and could in practice opt for a gradual approach to the setting up of their domestic ABs framework, first through interim policy and administrative measures ${ }^{41}$ and then legislative measures. This would allow Parties to comply with Article 6(3) in the context of timeconsuming legislative processes and in dealing with unprecedented legal questions at the domestic level. ${ }^{42}$ In these situations, users should ensure they consult with national authorities competent to implement the Nagoya Protocol in a given country, who could be mandated to advise on interim procedures and requirements for PIC and MAT. ${ }^{43}$ Provider countries, in turn, would be well advised to promptly identify competent national authorities while the domestic ABs framework is being developed. ${ }^{44}$ Overall, peer learning and developing guidance at the international level (to be agreed upon by the Protocol's governing body $)^{45}$ in this regard would certainly be welcome.

It should be further noted that a vast variety of situations could be possible, including Parties waiving their right to PIC and still regulating otherwise access to their genetic resources (for instance, by allowing free access to their genetic resources, but requiring users to establish MAT directly with private providers and provide information to relevant authorities for inclusion into a national register). In these cases, waiving PIC does not necessarily mean renouncing to benefit-sharing. ${ }^{46}$

40 In particular due to the linkages between Nagoya Protocol Article 6(3) and the compliance-related provisions under Articles 15-18.

41 On whether policy and administrative measures would qualify as 'domestic ABs legislation or regulatory requirements', for the purposes of triggering the compliance provisions of the Protocol (Articles 15-16), see this commentary on Article 15, section 3.1. See discussion on law-making capacity issues raised by the Nagoya Protocol in this commentary on Article 22.

43 Nagoya Protocol Article 13(2): see this commentary on Article 13, section 3.

44 We are grateful to Geoff Burton for drawing our attention to this point.

45 Article 26(4)(a): see this commentary on Article 26, section 2.

46 See this commentary on Article 5, section 2. 


\subsection{The Concept of State PIC}

PIC is a well-known tool in international law, used in and adapted to different contexts. ${ }^{47}$ It has been used widely in international instruments in the fields of chemicals and hazardous waste. ${ }^{48}$ In that context, it was based on the principle that prior to an activity involving risks, those affected and authorized to make a decision should be informed in detail about the potential risks, and was used to protect importing countries from environmental and health hazards. The concept has been used differently in the СвD context, as a tool to protect countries' sovereignty over natural, including genetic, resources.

Like the CBD, the Protocol's provisions on access are based on the concept of PIC, as an expression of the principle of national sovereignty over natural resources. In this case, therefore, PIC is meant to protect the Party providing genetic resources, rather than the one acquiring them. ${ }^{49}$ This means that, to give its consent to a request for access to genetic resources, the provider country must be informed in advance and in detail about the envisioned research or bioprospecting activity from the applicant. On the basis of this information, the competent authority ${ }^{50}$ of the provider country makes a decision regarding the access request, ${ }^{51}$ and sets (or orders the negotiation of) the MAT that will apply to the transaction. According to the Protocol provisions, the country's national ABs framework must include a procedure by which the decision on PIC is documented at the time of access by the issuance of a permit or its equivalent. ${ }^{52}$

47 One example of its use in international environmental instruments is found in the FAO International Code of Conduct on the Distribution and Use of Pesticides: "International Code of Conduct on the Distribution and Use of Pesticides" in FaO Council Resolution 1/123 "Revised Version of the International Code of Conduct onthe Distribution and Use of Pesticides" (1 November 2002). See Greiber et al., Explanatory Guide, op. cit., 95.

48 Rotterdam PIC Convention; see generally Katharina Kummer Peiry, "Prior Informed Consent," in Wolfrum, Max Planck Encyclopedia, op. cit.

49 Note that in the context of the Biosafety Protocol, свр Parties opted for using the Advance Informed Agreement, rather than PIC, as the central administrative procedure for regulating transboundary movements of living modified organisms. The Advance Informed Agreement procedure was loosely modelled along the PIC processes of the Rotterdam PIC Convention and Basel Convention on the Control of Transboundary Movements of Hazardous Wastes and their Disposal (Basel, 22 March 1989, in force 05 May 1992) 1673 unts 57, but allowing for a greater degree of flexibility. See Mackenzie et al., Explanatory Guide to the Cartagena Protocol, op. cit., 63.

5o See this commentary on Article 13, section 3.

51 Greiber et al., Explanatory Guide, op. cit., 95.

$5^{2}$ Nagoya Protocol Article 6(3)(e). On the internationally recognized certificate of compliance, see this commentary on Article 17, section 3. 
Parties to the Nagoya Protocol have discretion to exercise their right to require PIC fully or partially, or fully exempt access from the PIC requirement. A Party may decide, for instance, to use as criteria for exemption from the PIC requirement the ownership (public or private), location (for example, within or outside protected areas), type (plant, animal, aquatic, forest, micro-organisms) of genetic resources or the intent of the research envisioned (non-commercial or commercial purpose, or aiming to address health emergencies, or agricultural research purposes). ${ }^{53}$

Access to Genetic Resources Held by Indigenous and Local Communities

State PIC, as enshrined in the СвD and the Protocol, should be differentiated from indigenous and local community PIC. Article 6(2) represents a notable development with respect to the Convention, as well as from an international human rights perspective. ${ }^{54}$ It is the first international legally binding provision explicitly and specifically addressing the regulation of access to genetic resources 'held by' indigenous and local communities. The provision, however, is heavily qualified, both by reference to cases where communities have 'the established right' to grant access to such resources and by reference to 'in accordance with national legislation,' in parallel with Article 5(2).

Parties are required to take domestic measures to ensure that community PIC, or approval and involvement, is obtained. The Protocol does not, therefore, directly recognize rights for indigenous and local communities to grant access to genetic resources in their territories. Rather, it requires Parties to put legislation or other domestic measures in place on community PIC (or approval and involvement) in case communities' rights over genetic resources are already established or will be explicitly established in the future. The provision therefore embodies a 'community PIC requirement' that is separate from

53 See this commentary on Article 8.

54 Bavikatte and Robinson note: 'If we approach the law as a site of struggle, Article 6(2) of the Nagoya Protocol is a monumental achievement by communities. It is a testimony to six years of hard work and careful lobbying and has extended the scope of Article 8(j) in ways that were inconceivable in 1993. It had capitalised on the important victory ... that for indigenous peoples and local communities, there is an inseparable link between genetic resources and traditional knowledge.' See Kabir Bavikatte and Daniel F. Robinson, "Towards a People's History of the Law: Biocultural Jurisprudence and the Nagoya Protocol on Access and Benefit Sharing," Law, Environment and Development 7 (2011): 35, 47. 
(and possibly additional to) State PIC for access to relevant genetic resources pursuant to Article 6(1). As discussed in relation to the corresponding Protocol provisions on benefit-sharing for indigenous and local communities, ${ }^{55}$ these provisions may be considered an implicit recognition of an underlying substantive environmental right of these communities to their genetic resources. Article 6(2) specifies the UNDRIP standard on PIC concerning the use of indigenous peoples' natural resources in as far as it concerns genetic resources used for research and development. ${ }^{56}$ The Nagoya Protocol also goes beyond existing international human rights standards by extending the community PIC requirement to local communities.

The following analysis of Article 6(2) and its implications will focus first on the contours of Parties' obligations with respect to genetic resources held by indigenous and local communities (that is, how Parties will comply with the Protocol's community PIC requirement); and then on the concept of 'community PIC' (or approval and involvement) concerning genetic resources. ${ }^{57}$

\subsection{Parties' Obligation}

With regard to the community PIC requirement established by the Protocol, the mandatory wording of Article 6(2) ('shall') leaves little doubt that Parties are under an obligation to enact domestic measures with the aim of ensuring PIC (or approval and involvement) for indigenous and local communities that hold genetic resources within their jurisdiction. This requirement therefore limits the discretion of those Parties considering not requiring PIC for access to genetic resources in accordance with Article 6(1). At the same time, the qualifications found in the text ('in accordance with domestic law' and 'as appropriate') leave a degree of discretion to Parties with regard to the types of measures to be taken for the implementation of the community PIC requirement. The term 'as appropriate', however, does not leave discretion with regard to whether to take any domestic measures at all on this matter, as long as indigenous or local communities are found in the territory ${ }^{58}$ and have established

55 Nagoya Protocol Article 5(2). See this commentary on Article 5, section 3.

56 UNDRIP Article 32(2) reads: 'States shall consult and cooperate in good faith with the indigenous peoples concerned through their own representative institutions in order to obtain their free and informed consent prior to the approval of any project affecting their... resources, particularly in connection with the development, utilization or exploitation of mineral, water or other resources' (emphasis added).

57 For a complementary discussion of community PIC in relation to traditional knowledge, see this commentary on Article 7, section 2.

$5^{8}$ On the identification of indigenous peoples and local communities, in the absence of an international definition, see Introduction to this commentary, section 4. 
rights over genetic resources. ${ }^{59}$ As for other provisions in the Protocol that relate to indigenous peoples and local communities, Article 6(2) is to be interpreted and implemented in the light of relevant international human rights standards, ${ }^{60}$ and with due consideration of communities' customary laws, protocols and procedures. ${ }^{61}$

A difficulty, however, arises from the reference in Article 6(2) to 'the established right' for indigenous and local communities to grant access to genetic resources. Depending on its interpretation, this qualification could prove highly limiting for the involvement of indigenous and local communities in $\mathrm{ABS}$ transactions concerning genetic resources in their territories. The reference reflects language in Article 5 on benefit-sharing arising from the use of genetic resources held by communities, and the same considerations already discussed in that context apply here. ${ }^{62}$ According to a narrow interpretation, the term 'established' may only refer to situations where a particular community can demonstrate that its right to genetic resources is already affirmed in the domestic legal order, possibly leaving it to the absolute discretion of the Party concerned to determine whether such community rights exist and therefore whether or not to develop domestic measures on community PIC on genetic resources. ${ }^{63}$ This, however, appears overly restrictive and not in harmony with international human rights standards and the Protocol objective. ${ }^{64} \mathrm{~A}$ broader interpretation of 'established rights' on the basis of relevant international human rights law and in light of community customary laws would instead imply an obligation for Parties to map customary rights at the domestic level, in consultation with the concerned communities, ${ }^{65}$ provide for their legal recognition, and enact domestic measures to ensure community PIC in case communities' customary rights are ascertained. The inseparable nature of genetic resources and traditional knowledge for indigenous and local communities ${ }^{66}$ further substantiates the need for a broader interpretation of Article 6(2): as

\footnotetext{
59 See Introduction to this commentary, section 5 and fn. 225.

6o See Introduction to this commentary, section 4.

61 Nagoya Protocol Article 12(1). See this commentary on Article 12, section 2.

62 See this commentary on Article 5, section 3.2.

63 This possible interpretation was identified with concern by Singh Nijar, The Nagoya Protocol: Analysis and Implementation Options for Developing Countries, op. cit., 25-26.

64 See this commentary on Article 1, section 3.

65 UNDRIP Articles 19 and 32(2); ILo Convention No. 169, Article 6(2). See also Sarayakuv. Ecuador, paragraph 165.

66 Nagoya Protocol 22nd preambular recital.
} 
noted below, ${ }^{67}$ the obligation for Parties to enact domestic measures to ensure community PIC to traditional knowledge associated with genetic resources is not conditioned on the existence of specific rights.

\subsection{The Concept of Community PIC Concerning Genetic Resources}

While State PIC is premised on the general principle of national sovereignty over natural resources, community PIC for access to genetic resources is based on international human rights law, namely indigenous peoples' rights to: manage their natural resources; ${ }^{68}$ maintain and strengthen their distinctive spiritual relationship with their traditionally owned resources; ${ }^{69}$ own, use, develop and control the resources that they possess by reason of traditional ownership or use; ${ }^{70}$ be secure in the enjoyment of their own means of subsistence and development; ${ }^{71}$ and obtain just and fair redress if deprived of their means of subsistence and development, ${ }^{72}$ or dispossession of their resources. ${ }^{73}$

Community PIC is in fact a well-known tool in the human rights field, where it has been interpreted as integrating both 'positive' and 'defensive' protection sides. ${ }^{74}$ As a positive tool, PIC is used to empower indigenous peoples by giving them the right to control and benefit from the use of their natural resources. As a defensive tool, for instance with regard to development projects affecting indigenous peoples' lands and resources, PIC focuses on the potential negative impacts of the proposed activity - this is a connotation that is more akin to the

$67 \quad$ See this commentary on Article 7, section 2.

68 UNDRIP Article 3. For the relevance of these and other sources on indigenous peoples' human rights with respect to local communities, see Introduction to this commentary, section 4.2.

69 UNDRIP Article 25.

70 UNDRIP Article 26(2). On the international judicial recognition of the right to 'dispose of their natural resources', see Fodella, “Indigenous Peoples," op. cit., 350-1 and fns. 5 and 15-16; Human Rights Committee, Mahuika et al. v. New Zealand, Communication no. 547/1993 Views (27 October 2000), un Doc CCPR/C/70/D/547/1993, paragraph 9(2); Committee on the Elimination of Racial Discrimination (CERD), "General Recommendation No. 23," paragraph 5.

71 UNDRIP Article 20(1).

72 UNDRIP Article 20(2).

73 UNDRIP Article 8(2)(b).

74 СвD Working Group on Article 8(j), "How Tasks 7, 10 and 12 could best contribute," UNEP/ Сво/ WG8J/8/4/Rev.2, paragraph 43. On the international judicial recognition of the right to PIC, see sources analysed by Fodella, "Indigenous Peoples," op. cit., 350-352 and fns. 6, 13,17 and 20. 
use of PIC in multilateral chemicals conventions than in the CBD. ${ }^{75}$ Given that СвD Parties have not yet elaborated consensus guidance on community PIC concerning their genetic resources, it appears useful to draw on international human rights standards on community PIC for access to natural resources or, mutatis mutandis, on community PIC to developments/extractive activities in their lands.

In the context of international human rights processes, community PIC has been interpreted as entailing that consent should be given freely, without coercion, intimidation or manipulation (hence, the emphatic use of 'free' before PIC in UNDRIP). ${ }^{76}$ In addition, it should be sought sufficiently at all stages, from the inception to the final authorization and implementation of proposed activities ('prior'). It should be based on an understanding of the full range of issues and implications entailed by the activity or decision in question ('informed'), and given by the legitimate representatives of the indigenous peoples concerned. ${ }^{77}$ With a view to providing indigenous peoples with 'full and objective information about all aspects of the project that will affect them, including the impact of the project on their lives and environment,' an environmental and socio-cultural impact study should be carried out and its outcome should be presented to indigenous communities concerned at an early stage of the consultations preceding the community's decision on PIC. ${ }^{78}$

75 See however "Akwé: Kon Guidelines for the Conduct of Cultural, Environmental and Social Impact Assessment regarding Developments Proposed to Take Place on, or which are Likely to Impact on, Sacred Sites and on Lands and Waters Traditionally Occupied or Used by Indigenous and Local Communities" in свD Decision 7/16, "Article 8(j) and related provisions" (13 April 2004) un Doc UNEP/CBD/COP/DEC/VII/16 (hereinafter, Akwé: Kon Guidelines). On the risks that knowledge exchanges may entail for indigenous peoples and local communities, see Terry Williams and Preston Hardison, "Culture, Law, Risk and Governance: Contexts of Traditional Knowledge in Climate Change Adaptation," Climatic Change (2013) 120: 531.

76 In strictly legal terms, 'consent' is always free as the notion inherently embodies the absence of any coercion. See Findlaw Legal Dictionary, accessed 30 November 2013, <http://dictionary.findlaw.com/definition/consent.html >: 'compliance in or approval of what is done or proposed by another; (...) the voluntary agreement or acquiescence by a person of age or with requisite mental capacity who is not under duress or coercion and usually who has knowledge or understanding. In fact, coercion nullifies/invalidates any expression of consent.' (emphasis added). Compare Greiber et al., Explanatory Guide, op. cit., 110-111.

77 UNPFII, "Report on the tenth session," E/2011/43-E/C.19/2011/14, paragraphs 34-38, particularly paragraph 34 .

78 Human Rights Council, "Promotion and protection of all human rights, civil, political, economic, social and cultural rights, including the right to development. Report of the 
Several challenges arise for States to ensure community PIC. International human rights bodies have confirmed that PIC 'does not necessarily require unanimity and may be achieved even when individuals or groups within the community explicitly disagree. ${ }^{79}$ Nonetheless, States are still responsible to ensure the genuine involvement of legitimate representatives of indigenous peoples and the true nature of 'consent' in the context of indigenous customary institutions, including applicable customary decision-making processes and taking into account that consent may be withdrawn at a later stage. ${ }^{80}$ States are also expected to ensure that women and other potentially disenfranchised groups are included in the community PIC process. ${ }^{81}$

Overall, what emerges hitherto from relevant human rights processes is that PIC entails good-faith and culturally-appropriate consultation procedures, according to the communities' customs and traditions, where every effort is made to build consensus on the part of all concerned in reaching an agreement that is seen as legitimate by the community ${ }^{82}$ and leads to benefitsharing arrangements that must accord with indigenous peoples' own understanding of benefits. ${ }^{83}$ Thus, assimilating PIC to a veto power for communities, referring to the possibility to reject a proposal without providing adequate justification, is an oversimplification. ${ }^{84}$ Ultimately, the right to PIC is seen as a

Special Rapporteur on the situation of human rights and fundamental freedoms of indigenous people, James Anaya" (15 July 2009) un Doc A/HRC/12/34, paragraph 53. See also: Saramaka People v. Suriname 2007, parapgraph 134; African Commission on Human and Peoples' Rights, Social and Economic Rights Action Centre and Centre for Economic and Social v. Nigeria, Communication no. 155/96 (27 October 2001), paragraph 53; and Fodella, "Indigenous Peoples," op. cit., 356 and 360.

79 UN General Assembly, "Human rights and transnational corporations and other business enterprises," paragraph 11 .

$80 \quad$ Ibid.

81 Ibid. See also Nagoya Protocol 11th preambular recital and Article 12(3)(b), and brief discussion on the challenges in tackling discrimination based on gender in the Introduction to this commentary, section 4.3.

82 Human Rights Council, "Promotion and protection of all human rights," A/HRC/12/34, paragraphs $46-48$.

83 Human Rights Council, "Follow-up report on indigenous peoples and the right to participate in decision-making, with a focus on extractive industries" (16 August 2012) un Doc A/Hrc/21/55, paragraph 43; also un General Assembly, "Report of the Special Rapporteur on the rights of indigenous peoples" (13 August 2012) UN Doc A/67/301, paragraph 78.

84 Human Rights Council, "Promotion and protection of all human rights," A/HRC/12/34, paragraphs 46-48; and Human Rights Council, "Report of the Special Rapporteur on indigenous peoples' rights," A/HRC/24/41, paragraph 30 , which reads '... But it must be 
procedural safeguard for the exercise of indigenous peoples' substantive right to self-determination, including their rights to property, culture, religion and non-discrimination, as well as the right to set and pursue their own priorities for development. ${ }^{85}$ Despite conceptual progress at the international level, however, ${ }^{86}$ questions remain concerning the implementation of the right to community PIC. ${ }^{87}$ In addition, the community PIC requirement may be particularly challenging to implement when two or more indigenous peoples or local communities share genetic resources. ${ }^{88}$

emphasized that the consent is not a free-standing device of legitimation. The principle of free, prior and informed consent, arising as it does within a human rights framework, does not contemplate consent as simply a yes to a predetermined decision, or as a means to validate a deal that disadvantages affected indigenous peoples. When consent is given, not just freely and on an informed basis, but also on just terms that are protective of indigenous peoples rights, it will fulfil its human rights safeguard role'.

85 Human Rights Council, "Report of the Special Rapporteur on the rights of indigenous peoples, James Anaya” (6 July 2012) UN Doc A/HRC/21/47, paragraph 50; and Human Rights Council, "Report of the Special Rapporteur on indigenous peoples' rights," A/HRC/24/41, paragraph 28 .

86 E.g., UNPFII, "Report of the international workshop on methodologies regarding free, prior and informed consent and indigenous peoples" (17 February 2005) UN Doc E/C.19/2005/3; "Report of the international technical workshop on indigenous traditional knowledge" (15 December 2005) un Doc E/C.19/2006/2); "Report on the fifth session" (13 June 2006) Un Doc. E/2006/43-E/C.19/2006/11; and "An overview of the principle of free, prior and informed consent and indigenous peoples in international and domestic law and practices. Contribution by Parshuram Tamang Paper prepared for the UNPFII workshop on free, prior and informed consent" (17-19 January 2005) UN Doc PFII/2004/ ws.2/8.

87 The Permanent Forum has therefore indicated that it will explore the opportunity to develop guidelines on the implementation of free PIC, in collaboration with the UN Expert Mechanism on the Rights of Indigenous Peoples and the Special Rapporteur on the Rights of Indigenous Peoples: UnPfiI, "Report on the tenth session," E/2011/43E/C.19/2011/14, paragraph 37 .

88 We are grateful to Geoff Burton for drawing our attention to this point. The Nagoya Protocol only addresses situations in which traditional knowledge is shared by different indigenous and local communities located in different States (Article 11(2); see this commentary on Article 11, section 4), although it can be argued that the provision on inter-State cooperation in relation to genetic resources found in situ within the territory of more than one Party can also include instances in which different indingeous and local communities in different Parties share genetic resources (Article 11(1); ); see this commentary on Article 11, section 3). 


\subsubsection{Approval and Involvement}

The reference to 'or approval and involvement' in Article 6(2) reiterates the wording of СвD Article 8(j) and reflects the reluctance by some СвD Parties to fully endorse in the Protocol the right to community PIC as developed in international human rights law and enshrined in UNDRIP. The expression 'approval and involvement' was introduced in the Protocol in order to allow for a greater degree of flexibility in implementation at the national level, ${ }^{89}$ in the light of different domestic legal arrangements concerning the relations between governments and indigenous and local communities within their territories. ${ }^{90}$ This reluctance is also illustrated by the timid preambular reference to UNDRIP, ${ }^{91}$ and by references to 'PIC and approval and involvement' in previous CBD COP decisions. ${ }^{92}$ The matter continues to remain very contentious in relevant discussions under the $\mathrm{CBD}$ at the time of writing, ${ }^{93}$ although

89 Caution about using PIC in the Nagoya Protocol text was explained by the possible implication of "creating/expanding "sovereign rights" for communities to control genetic resources that would run against constitutional provisions or domestic practices in certain countries': Burton, "Implementation of the Nagoya Protocol in Juscanz Countries," op. cit., 318-328, particularly 318-319. See also свD Working Group on ABs, "Concerns relating to (22 September 2010) Un Doc UnEP/CBD/WG-ABS/9/INF/21. For an academic argument on 'parallel' sovereignty of States and indigenous peoples, see generally Lenzerini, "Sovereignty Revisited," op. cit.

$90 \quad$ "Joint submission Grand Council of the Crees (Eeyou Istchee)," 133-136, and comments by Savaresi, "International Human Rights Law Implications," op. cit., 70. The Special Rapporteur on the Rights of Indigenous Peoples reported on concerns raised in the submission above, in UN General Assembly, "Report of the Special Rapporteur on indigenous peoples' rights," A/67/301, paragraphs 58-59. Buck and Hamilton, "Nagoya Protocol," op. cit., 55.

91 Nagoya Protocol 26th preambular recital simply 'notes' UNDRIP.

92 E.g., Bonn Guidelines, paragraph 31; and СвD Decision 5/16, paragraph 5: 'access to traditional knowledge, innovations and practices of indigenous and local communities should be subject to prior informed consent or prior informed approval from the holders of such knowledge...' Note, however, the 2004 Akwé: Kon Voluntary Guidelines refer consistently only to 'prior informed consent' (Akwé: Kon Guidelines, paragraphs 29, $52-53$ and 60).

93 For an indication of continued divergence of views on utilising UNDRIP language in the context of the CBD, see ENB, "Summary of the Seventh Meeting of the Working Group on Article 8(j) of the Convention on Biological Diversity: 31 October-4 November 2011," Vol. 9 No. 557, 7 November 2011, 5-6; and ENB, "Summary of the Eighth Meeting of the Working Group on Article 8(j) and 17th Meeting of the Subsidiary Body on Scientific, Technical and Technological Advice of the Convention on Biological Diversity: 7-18 October 2013," Vol. 9 No. 611, 21 October 2013, 4, 6-7 and 20. 
commentators have suggested that CBD Parties can consider the two expressions as having essentially the same meaning in practice. ${ }^{94}$

Given that the right to PIC is considered to imply the right for indigenous and local communities to allow or refuse ${ }^{95}$ access to their genetic resources, the crucial issue with regard to the alternative term 'approval and involvement' is whether it provides equal guarantees in the context of communities' own decision-making processes or communities' participation in government decision-making processes. ${ }^{96}$ In the latter case, it may well be that community PIC is embodied in the same decision embodying State PIC. This may raise particular difficulties in situations where ownership over genetic resources is not clarified in domestic ABs frameworks or where the government also asserts its own sovereignty over genetic resources held by communities and consultations with communities in this regard are inconclusive.

In this connection, the UN Special Rapporteur on Indigenous Peoples' Rights has recommended interpreting and implementing relevant international environmental treaties in a way that is consistent with UNDRIP, whether or not the specific text of these instruments matches exactly the terms of the Declaration. ${ }^{97}$ So, 'approval and involvement' should still provide

94 Singh Nijar, The Nagoya Protocol on ABs: An Analysis, op. cit., 26; Buck and Hamilton, "Nagoya Protocol," op. cit., 55; and Greiber et al., Explanatory Guide, op. cit., 110-111. Note that any community PIC process should be as far as possible determined and controlled by the particular indigenous community: Human Rights Council, "Promotion and protection of all human rights," A/HRC/12/34; Human Rights Council, "Report of the Special Rapporteur on indigenous peoples' rights," A/H RC/24/41 paragraphs 26-36; CERD, "General Recommendation No. 23;" and Human Rights Committee, Ángela Poma Poma v. Peru, Communication No. 1457/2006, (27 March 2009) Un Doc CCPR/C/95/D/1457/2006.

95 A definition recently discussed (but not intergovernmentally approved) in the CBD framework considers PIC as the procedure through which indigenous or local communities properly supplied with all the required information, decide to allow or refuse access to their traditional knowledge under mutually agreed conditions of equality, respect and fair compensation. See "Set of relevant definitions/glossary of terms for Article 8(j) and related provisions," in свD Article 8(j) Working Group, "Development of elements of sui generis systems for the protection of traditional knowledge, innovations and practices. Note by the Executive Secretary" (24 November 2005) UN Doc UNEP/ СвD/WG $8 J / 4 / 7$, Annex II, which refers to UNPFII, "Report of the international workshop on methodologies regarding free, prior and informed consent and indigenous peoples," E/C.19/2005/3, emphasis added.

96 E.g., the Sami People have set up Sami parliaments that constitute an integral part of the governmental structure in Sweden, Finland and Norway ("Politics," Sami People, accessed 6 February 2014, <www.eng.samer.se/servlet/GetDoc?meta_id=1009>).

97 UN General Assembly, "Report of the Special Rapporteur on indigenous peoples' rights," A/67/301, paragraphs 92 and 61, where the Special Rapporteur specifically expresses the 
a genuine and effective guarantee to uphold indigenous peoples' right to selfdetermination and to protect their rights over genetic resources found in their territories, by empowering them to 'effectively determine the outcome of decision-making ... not merely a right to be involved in such processes. ${ }^{98}$ Thus, when States claim ownership on, or otherwise assert the power to expropriate community property interests in, genetic resources in order to have or permit access to these resources, this amounts to a limitation of community rights, including their right to property and culture, even if those rights are not held under a title deed or other form of official recognition, and even if just compensation is provided. Such expropriation can only be considered valid from an international human rights perspective if it is pursuant to a valid public purpose, which cannot be a mere commercial interest, revenue-raising objective, or the conduct of activities that are primarily for private gain. ${ }^{99}$ In addition, the limitation must comply with standards of strict necessity and proportionality, be determined by law and be non-discriminatory. ${ }^{100}$

Furthermore, even if it is an alternative standard to PIC, 'approval and involvement' should be interpreted and applied also in light of more general international human rights standards such as the right to access information, participation and transparency in decision-making and access to adequate remedies. ${ }^{101}$ Ultimately, Parties to the Protocol will need to strike an equitable balance between the need to establish some formal processes to effectively engage indigenous and local communities in good faith when access to genetic resources in their territories is requested and the need to genuinely respect their rights as enshrined in international human rights law. ${ }^{102}$

'hopeful expectation' that the provisions of the Nagoya Protocol will be implemented 'in harmony with' UNDRIP.

98 Expert Mechanism on the Rights of Indigenous Peoples, "Advice No. 2, Indigenous peoples and the right to participate in decision-making," (2011), accessed 30 October 2012, <www.ohchr.org/Documents/Issues/IPeoples/EMRIP/Advice2_Oct2011.pdf>, paragraph 1, emphasis added.

99 Human Rights Council, "Report of the Special Rapporteur on indigenous peoples' rights," A/HRC/24/41, paragraph 35 .

100 Ibid.; and UNDRIP Article 46(2).

101 Savaresi, "International Human Rights Law Implications," op. cit., 70. Compare with ICCPR Article 2(3), although the latter refers only to access to remedies.

102 See Human Rights Council, "Report of the Special Rapporteur on indigenous peoples' rights," A/HRC/24/41, paragraph 25. We are grateful to Annalisa Savaresi for a useful exchange of ideas on this matter. 


\subsubsection{Community PIC and Private-sector Users}

International human rights processes have started to provide guidance on the role of States in legislating for, and supporting community PIC vis-à-vis private developers, and have also elaborated on private operators' own responsibility to respect community PIC. ${ }^{103}$ These international developments, that are based on the recognition that community PIC and the substantive human rights tied to PIC requirements are often directly affected by business, ${ }^{104}$ may have significant resonance in the context of community PIC and ABS transactions involving private parties.

In that connection, the duty of States to protect indigenous peoples' rights applies also when granting permits to private parties relating to indigenous peoples' resources, ${ }^{105}$ and includes the obligation to provide business with clarity on the right of indigenous peoples in that regard, including when indigenous peoples do not have a State-recognized title to the lands and resources affected by extractive activities. ${ }^{106}$ States are also called upon to establish mechanisms and procedures to verify that community PIC has been sought by private-sector operators, and to include indigenous peoples in the development of such mechanisms. Should these mechanism lead to the determination that community PIC has not been respected, the State may revoke any authorization given. ${ }^{107}$ These indications can certainly apply to provider countries under the Protocol.

With regard to user countries, even if no indigenous peoples reside within their borders, other indications from human rights bodies appear relevant, particularly for home States of transnational corporations operating in territories

103 Elisa Morgera, "From Corporate Social Responsibility to Accountability Mechanisms," in Harnessing Foreign Investment to Promote Environmental Protection Incentives and Safeguards, ed. Pierre-Marie Dupuy and Jorge E. Viñuales (Cambridge: Cambridge University Press, 2013), 321.

104 UN General Assembly, "Human rights and transnational corporations," A/68/279, paragraph 10.

105 ILo Convention No. 169 Article 15(1); Inter-American Commission on Human Rights, Maya Indigenous Community of the Toledo District v. Belize, Merits, Judgment, Case no. 12.053 (12 October 2004), 194-195 (hereinafter, Maya Indigenous Community v. Belize); and, more generally, Inter-American Commission on Human Rights, "Indigenous and Tribal Peoples' Rights over Their Ancestral Lands and Natural Resources. Norms and Jurisprudence of the Inter-American Human Rights System," American Indian Law Review 35 (2010): 386.

106 Human Rights Council, "Follow-up report," A/HRc/21/47, paragraphs 32-35; and Human Rights Council, "Report of the Special Rapporteur on indigenous peoples' rights," A/HRC/24/41, paragraphs 26-40.

107 UN General Assembly, "Human rights and transnational corporations," A/68/279, paragraph 11. 
used or inhabited by indigenous peoples. ${ }^{108}$ In particular, user countries are to consider ways to ensure that indigenous peoples affected by the operations of their biotech multinationals abroad have access to effective remedy, ${ }^{109}$ taking into account the specificities of indigenous peoples and ensuring that any barriers to their access to the mechanisms are addressed and removed. ${ }^{110}$

With regards to business enterprises' own responsibility to respect human rights, ${ }^{111}$ companies' due diligence is increasingly expected to factor in risks related to the respect for indigenous peoples' rights, in particular respect for their collective rights to lands and resources in accordance with their own customary laws, traditions and practices. ${ }^{112}$ Companies' policies are expected to include a commitment to seek to ensure respect for community PIC, based on international human rights law, including UNDRIP and ILO Convention 169.113 This should be operationalized through the conduct of human rights impact assessment, ${ }^{114}$ leverage in business relationships to prevent and address adverse impacts, and the exercise of regular and direct consultations with indigenous peoples when their human rights may be affected, taking into account language and other potential barriers to effective engagement. In addition, companies are expected to establish mediation-based and culturally appropriate operational-level grievance mechanisms that take into account traditional indigenous mechanisms. ${ }^{115}$ Specific reference, in that context, is made to business' responsibility to respect PIC in relation to benefit-sharing arrangements that must accord with indigenous peoples' own understanding

\footnotetext{
108 Ibid., paragraph 55(a).

109 Ibid., paragraph 55(j). See also this commentary on Article 18.

110 Ibid., paragraph 37.

111 Human Rights Council, "Report of the Special Representative of the Secretary-General on the issue of Human Rights and Transnational Corporations and Other Business Enterprises: Protect, Respect and Remedy: A Framework for Business and Human Rights" (7 April 2008) UN Doc A/HrC/8/5; and "Guiding Principles on Business and Human Rights to implement the UN Protect, Respect and Remedy Framework" (21 March 2011) UN Doc A/HRC/17/31, paragraph 11.

112 UN General Assembly, "Human rights and transnational corporations," A/68/279, paragraph 24.

113 Ibid., paragraph 56.

114 Note that the relevance of the СвD Akwé: Kon Guidelines in this respect has already been highlighted by human rights bodies: see discussion in Morgera, "From Corporate Social Responsibility to Accountability Mechanisms," op. cit., 335-336 and 348-349.

115 UN General Assembly, "Human rights and transnational corporations," A/68/279, paragraph 56; Human Rights Council, “Follow-up report," A/HRc/21/47, paragraph 28(d); and Human Rights Council, "Report of the Special Rapporteur on indigenous peoples' rights," A/HRC/24/41, paragraph 78.
} 
of benefits. ${ }^{116}$ These indications are clearly relevant to private-sector users under the Protocol.

Consequently, in the absence of an adequate State-led process to ensure community PIC, private-sector users may need to consider carefully whether they can proceed with access to genetic resources without the risk of causing or contributing to adverse impacts on the rights of indigenous peoples. ${ }^{117}$ This in effect provides an incentive for provider and user countries to establish appropriate measures on community PIC, with a view to attracting responsible users.

\section{5}

\section{Access Standards}

When a Party develops domestic measures on access to its genetic resources, it has discretion in choosing legislative, administrative or policy measures 'as appropriate.' Each Party will therefore have to determine what types (or what mix) of measures are necessary to regulate access to its genetic resources domestically. The choice will reflect the constitutional, legal and administrative context of a Party, and will also likely be based on an assessment of the capacities and resources to implement and enforce the proposed ABs framework (in the case of developing countries, the Protocol provisions on capacity and financial support are therefore relevant). ${ }^{118}$

In developing domestic access measures, Parties must respect a series of 'standards' 119 and include a series of minimum requirements that are detailed in Article 6(3) $(\mathrm{a}-\mathrm{g})$. The list of standards and requirements is cumulative. Parties therefore do not have discretion to implement only one or other standard/requirement from the list - with the exception of the criteria and

116 Human Rights Council, "Follow-up report," A/HRC/21/47, paragraph 43; and Human Rights Council, "Report of the Special Rapporteur on indigenous peoples' rights," A/ $\mathrm{HRC} / 21 / 47$. On benefit-sharing and business' responsibility to respect human rights, see Elisa Morgera, "Environmental Accountability of Multinational Corporations: BenefitSharing as a Bridge between Human Rights and the Environment," in The Environmental Dimension of Human Rights, ed. Ben Boer (Oxford: Oxford University Press, forthcoming, 2014).

117 UN General Assembly, "Human rights and transnational corporations," paragraph 21.

118 See this commentary on Articles 22 and 25.

119 The Protocol negotiators referred to Article 6(3)(a-g) as 'international access standards' and this were among the most contentious issues in the negotiation of the Nagoya Protocol: Buck and Hamilton, "Nagoya Protocol," op. cit., 51. As the commentary will discuss below, however, only Article 6(a-b) can be technically considered legal 'standards.' 
processes to obtain community PIC, because it is the only requirement qualified by 'where applicable.'120 Parties may, however, go beyond the standards and requirements set out in Article 6(3), which can be considered a minimum necessary to support user countries in understanding the applicable rules of the provider country, and therefore be put in an easier position when implementing their compliance-related obligations under the Protocol. ${ }^{121}$

Some commentators have criticized the standards contained in Article 6(3) because they are framed in too general terms and do not appear amenable to an objective assessment of whether domestic measures satisfy them or not. ${ }^{122}$ In general international law, legal provisions of a more general normative content than rules ${ }^{123}$ can be considered legal standards.'124 They imply the idea of a level or model to which to conform and with reference to which one can evaluate or critically appraise certain behavior.'125 In other words, they provide a legal benchmark allowing an appreciation of whether a certain con-

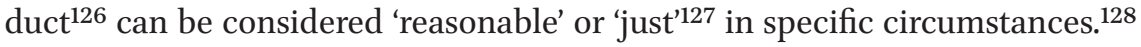

120 Nagoya Protocol Article 6(3)(f).

121 See this commentary on Articles 15-18.

122 Gurdial Singh, The Nagoya Protocol: An Analysis, op. cit., 16. The concern may be understood in the light of a proposal to allow user countries to decide whether and to what extent users' non-compliance in their jurisdictions was partly due to deficiencies in the domestic ABS framework of a provider country. The EU maintained until September 2010 bracketed text to this effect in draft article 12(2) in Montreal I Draft: 'Parties may refrain from taking such measures if the domestic access and benefit-sharing framework of another Party providing the misappropriated genetic resources at the time of misappropriation was not in conformity with Article 5(2).'

123 According to Hart, rules require human beings to do or abstain from certain actions, whether they wish to or not: Herbert L. A. Hart, The Concept of Law (Oxford: Oxford University Press, 1994), 81.

124 Jean Salmon, ed., Dictionnaire de Droit International Public (Bruxelles: Bruylant, 2001), 1049; Abd Al-Razzâq Al-Sanhoury and Édouard Lambert, Les Restrictions Contractuelles à la Liberté Individuelle de Travail dans la Jurisprudence Anglaise. Contribution à l'étude Comparative de la Règle de Droit et du Standard Juridique (Paris: Marcel Giard, 1925).

125 These elements are suggested by Hart, The Concept of Law, op. cit., 32.

126 Jules Basdevant, ed., Dictionnaire de la Terminologie du Droit International (Paris: Sirey, 1960), 581. Pound, along the same lines, defines standards as 'measures of conduct prescribed by law from which one departs at his peril of answering for resulting damage': Roscoe Pound, Social Contract through Law (New Haven: Yale University Press, 1942) 44-49.

127 Ibid., 47-49.

128 Richard Dworkin, 'Is Law a System of Rules?' in The Philosophy of Law, ed. Richard Dworkin, (Oxford: Oxford University Press, 1977), 38, 43. 
Legal standards therefore involve an idea of striking a reasonable balance between legal requirements and legitimate expectations based on experience or on moral sentiment. ${ }^{129}$ It follows that legal standards are used when it would be 'unreasonable to attempt to formulate a definition of reasonable'130 ex ante.

Against this background, the recourse to legal standards in Article 6(3)(a-b) seems suitable to give direction to domestic implementation efforts while allowing for case-by-case determinations of the appropriate, context-specific measure on access that appear apt to reach the objective of the Protocol of realizing fair and equitable benefit-sharing, ${ }^{131}$ taking into account national legal and administrative traditions and constraints, as well as capacity needs particularly in the time period immediately following the entry into force of the Protocol. As the other provisions in Article 6(3)(c-g) clearly point to a specific conduct, rather than a legal standard, they will be discussed separately below, as minimum requirements.

The access standards and minimum requirements in Article 6(3) may contribute to a certain common approach to the development of domestic access rules that could facilitate the creation of an international functional ABs legal system (as applicants will better understand what is expected of them and enforcement in user countries may be easier). But it has been observed that the Protocol does not provide similar minimum standards and requirements also for benefit-sharing obligations. ${ }^{132}$ Proposals to this effect were considered during the negotiations. As opposed to establishing international standards in the Protocol, however, the proposal was to insert an obligation for Parties to establish domestically minimum conditions and standards for sharing results of research, and benefits arising from every commercial and other forms of utilization of genetic resources, derivatives and traditional knowledge, upon MAT, building on the list of monetary and non-monetary benefits that is now included the Protocol Annex. ${ }^{133}$ It can thus be argued that the Nagoya

129 Pound, Social Control through Law, op. cit., 80; Hart, The Concept of Law, op. cit., 132; and André-Jean Arnaud, ed., Dictionnaire Encyclopédique de Théorie et de Sociologie du Droit (Paris: Librairie Générale de Droit et de Jurisprudence, 1988), 581. For a more detailed discussion on standards, on which this section draws upon, see Elisa Morgera, Corporate Accountability in International Environmental Law (Oxford: Oxford University Press, 2009), 66-70.

130 Pound, Social Control through Law, op. cit., 48.

131 See this commentary on Article 1.

132 Under Nagoya Protocol Article 5. See Tvedt, "Beyond Nagoya," op. cit., 166.

133 Proposal by India in Свр Working Group on ABS, "Collation of operative text submitted," UNEP/CBD/WG-ABS/7/4, 13. 
Protocol rather encourages indirectly the achievement of substantive fairness of benefit-sharing conditions set out in MAT, through lessons learnt by various stakeholders that participate in the elaboration of model contractual clauses and voluntary instruments, ${ }^{134}$ and through training and capacity-building of relevant stakeholders. ${ }^{135}$

\subsection{Legal Certainty, Clarity and Transparency}

The first legal standard for domestic access measures is legal certainty, ${ }^{136}$ clarity and transparency. These concepts reflect very concrete concerns that had emerged in the development and implementation of national ABs frameworks preceding the conclusion of the negotiations of the Nagoya Protocol. These concerns include difficulties encountered by users in trying to obtain PIC to access genetic resources and ensuring that such access was indeed lawful under the provider countries' legal system. ${ }^{137}$ Legal certainty, clarity and transparency generally aim to promote the rule of law ${ }^{138}$ and good governance ${ }^{139}$ in the ABS context.

Based on a literal interpretation, legal certainty may refer to the role of law in providing those subject to it with an unambiguous basis on which to determine whether their actions are legal and thereby protecting them from arbitrary use of State power. ${ }^{140}$ Clarity may refer to sufficiently precise content and internal coherence that allow foreseeing, to a reasonable degree, the consequences of a given action. ${ }^{141}$ Transparency may refer to the provision of relevant information in a manner that is accessible and easily understandable to those affected, including information on how national authorities'

134 See this commentary on Articles 19-20.

135 See this commentary on Articles 21 and 12, section 4.

136 Nagoya Protocol Article 6(3)(a). See also Nagoya Protocol 9th preambular recital.

137 Tomme Young, "Summary Analysis: Legal Certainty for Users of Genetic Resources under Existing Access and Benefit-Sharing (ABS) Legislation and Policy," in Young, Covering A BS, op. cit., 77. See also Glowka and Normand, "The Nagoya Protocol on Access and Benefitsharing," op. cit., 29; and Cabrera Medaglia, "The Implementation of the Nagoya Protocol," op. cit., 357.

138 Simon Chesterman, "Rule of Law," in Wolfrum, Max Planck Encyclopedia op. cit., specifically section C "Promotion of the Rule of Law Through International Forums."

139 Edith Brown Weiss and Ahila Sornarajah, "Good Governance," in Wolfrum, Max Planck Encyclopedia, op. cit.

140 Greiber et al., Explanatory Guide, op. cit., 102.

141 Ibid., 103. 
decision-making on access, and implementation and enforcement of ABS decisions, comply with applicable rules and procedures. ${ }^{142}$

At the same time, however, these concepts have been elaborated in the context of other areas of international law, such as foreign investment and human rights. As to the latter, international case law has elaborated on the meaning of transparency in the context of procedural rights, such as the right of access to information and public participation in decision-making. ${ }^{143}$ As to the former, international investment case law has elaborated on notions of certainty, consistency and transparency with a view to protecting the reasonable expectations of investors vis-à-vis the application of domestic laws or their reform in as far as these may affect the stability and predictability of the legal and business framework in which investors operate. ${ }^{144}$ It remains to be seen whether and to what extent courts (or the Protocol's compliance mechanism) $)^{145}$ will take these indications into account if requested to assess compliance by Parties with this access standard. Other applicable international treaties, such as regional human rights treaties (note, in particular the relevance of the Aarhus Convention) or bilateral agreements, ${ }^{146}$ may also provide indications as to how this standard may be interpreted and expected to apply in specific countries.

142 Brown Weiss and Sornarajah, “Good Governance," op. cit. See also Greiber et al., Explanatory Guide, op. cit., 103.

143 Savaresi, "International Human Rights Law Implications," op. cit., 70-71.

144 Christoph Schreuer, "Investments, International Protection," in Wolfrum, Max Planck Encyclopedia, op. cit., 4; and Matthias Herdegen, "International Economic Law," in Wolfrum, Max Planck Encyclopedia, op. cit., 37. See also Thomas W. Wälde and Abba Kolo, "Coverage of Taxation under Modern Investment Treaties," in The Oxford Handbook of International Investment Law, ed. Peter Muchlinski, Federico Ortino and Christoph Schreuer (Oxford: Oxford University Press, 2008), 305, 356. See also Akira Kotera, "Regulatory Transparency," in Muchlinski, Ortino, and Schreuer, Oxford Handbook of International Investment Law, op. cit., 617; Todd J. Grierson-Weiler and Ian I. Laird, "Standards of Treatment," in Muchlinski, Ortino and Schreuer, Oxford Handbook of International Investment Law, op. cit., 259; Wenhua Shan, "Towards a Balanced Liberal Investment Regime: General Report on the Protection of Foreign Investment," ICSID Review 25 (2010): 421; and Michele Potestà, "Legitimate Expectations in Investment Treaty Law: Understanding the Roots and the Limits of a Controversial Concept," ICSID Review 28 (2013): 88.

145 See this commentary on Article 30.

146 See this commentary on Article 4, section 3. 


\subsection{Fair and Non-arbitrary Access Rules and Procedures}

The second standard for domestic access measures concerns fair and nonarbitrary rules and procedures. This expression appears to cover both substantive and procedural measures, and aims at providing guarantees against an unjustified or unreasonable exercise of discretion in the decision-making process $^{147}$ (that is, access decisions that are based on prejudice or personal preference). ${ }^{148}$ It may also extend to guarantees against excessive delays, ${ }^{149}$ or against corruption ${ }^{150}$ in domestic decision-making on access.

This provision was intensely negotiated, as an alternative to a reference to 'non-discriminatory'151 access measures, amidst developing countries' concerns that either expression would 'import' into the Protocol notions such as national treatment from international economic law. ${ }^{152}$ Negotiators debated whether provider countries could differentiate among foreign users depending on the domestic ABS framework of the users' country (that is, as an incentive for user countries to develop and implement appropriate domestic ABS systems that can effectively ensure compliance with the provider country's domestic ABS framework) or depending on whether the user country has ratified the СвD or the Nagoya Protocol. ${ }^{153}$ As the proposed reference to 'nondiscriminatory' was dropped from the Protocol's text, it can be assumed that such distinctions are acceptable as long as they support the effective functioning of the Protocol. This is the case of domestic ABS measures requiring

147 Krista Nadakavukaren Schefer, International Investment Law: Text, Cases and Materials (Cheltenham: Edward Elgar, 2013), 275.

148 Schreuer, “Investments, International Protection," op. cit., 60-62, who provides a concise review of relevant international case law.

149 Viñuales, Foreign Investment and the Environment, op. cit., 356. See also Nagoya Protocol Article 6(3)(d) and section 4 below.

150 We are grateful to Geoff Burton for drawing our attention to this point. See generally Kenneth W. Abbott, "Corruption, Fight against," in Wolfrum, Max Planck Encyclopedia, op. cit.

151 See draft article 5(2)(a bis) in Nagoya Draft, which reads: "[[Provide for equal treatment in applications for access to genetic resources between similar domestic and foreign applicants and between similar foreign applicants of different Parties][Parties shall avoid application of discriminatory rules in processing access permits except where such rules aim at advancing local, non-commercial biodiversity and ecosystem research and education][Provide for fair and non-arbitrary rules and procedures on accessing genetic resources];]" (brackets in the original). On environmental measures and nondiscriminatory standards, Viñuales, Foreign Investment and the Environment, op. cit., Ch. 13.

$15^{2}$ Singh Nijar “An Asian Developing Country's View," op. cit., 251-252.

153 Pavoni, "Nagoya Protocol and wTo Law," op. cit., 193. 
foreign users to be affiliated or represented by a local person or entity, ${ }^{154}$ with a view to encouraging capacity-building and non-monetary benefit-sharing; ${ }^{155}$ or accord preference to local users engaged in non-commercial biodiversity research. ${ }^{156}$ It may also be the case of users based in countries that have concluded a bilateral treaty with the provider country. 157

Similarly to Article 6(3)(a), the access standard concerning fair and nonarbitrary rules and procedures in Article 6(3)(b) resonates with concepts that have been elaborated in the context of international investment law, but also international human rights law. ${ }^{158}$ In international investment law, for instance, 'fair treatment' can be seen as a combination of the protection of legitimate expectations, good faith, transparency and consistency. ${ }^{159}$ 'Non-arbitrary' may point to the avoidance of unreasonable treatment that affects certain investors. ${ }^{160}$ In that context, it has also been emphasized that the concepts of 'non-arbitrariness' differs in international and national law: consequently, a national court's determination of arbitrariness based on national administrative law may be a useful indication, but not conclusive proof, of arbitrariness as it is understood at the international level. ${ }^{161}$ In other words, a broader notion of arbitrariness may be drawn on the basis of international investment law. ${ }^{162}$

154 Some examples of the latter can be found in Latin America: see Cabrera Medaglia, "The Implementation of the Nagoya Protocol," op. cit., 357-8. For potential wTo law incompatibility issues, see Pavoni, "Nagoya Protocol and wTo Law," op. cit., 195.

155 See this commentary on Articles 22 and 5.

${ }_{15} 6$ Greiber et al., Explanatory Guide, op. cit., 104. While a country may certainly differentiate among its own nationals and foreign users, the first instance will not need to be governed by the Nagoya Protocol rules, as it is a purely national situation.

157 See this commentary on Article 4, section 3.

$15^{8}$ Lorand Bartels, "Trade and Human Rights," in Wolfrum, Max Planck Encyclopedia, op. cit., 5 .

159 E.g. International Centre for Settlement of Investment Disputes, Biwater Gauff (Tanzania) Ltd v Tanzania, Case no ARB/05/22, Award (24 July 2008), paragraph 591, as commented upon by James Harrison, "United Kingdom Report on the Protection of Foreign Investment" (presented at the International Congress of Comparative Law, Washington DC, 2010). See generally, Viñuales, Foreign Investment and the Environment, op. cit., Ch 14.

16o Schreuer, "Investments, International Protection," op. cit., 57-66. We are thankful to James Harrison for a useful preliminary exchange of ideas on this point.

161 ICJ, Elettronica Sicula S.p.A. (ELSI) (United States of America v. Italy), Judgement (20 July 1989), paragraphs 124-125; as discussed in Nadakavukaren Schefer, International Investment Law, op. cit., 275.

162 For instance, procedural irregularities amounting to bad faith, wilful disregard of due process, or extreme insufficiency of action, measures inflicting damage on investor without serving any apparent legitimate purpose (reasonable and proportionate reaction 
It remains to be seen whether and to what extent courts (or the Protocol's compliance mechanism) will take these indications into account if requested to assess compliance by Parties with this access standard.

Even if the terms of the Protocol were not going to be interpreted in the light of international investment law, however, it cannot be excluded that an investment dispute settlement mechanism may be seized to consider whether restrictive domestic access provisions may conflict with the terms of bilateral investment treaties concluded by the provider country, ${ }^{163}$ including when the domestic access measures are specifically aimed at operationalizing the PIC requirement for access to genetic resources held by indigenous and local communities. In the latter case, provider countries may be well advised to justify their domestic access measures on the basis of relevant international human rights obligations, in addition to the relevant provisions of the Nagoya Protocol, as investment tribunals are generally reluctant to fully consider the implications of international environmental law for the disputes they are tasked to decide. ${ }^{164}$

\section{Minimum Procedural Requirements for PIC}

Article 6(3)(c-f) spells out minimum procedural requirements that must be included in domestic access frameworks of Parties requiring PIC. First of all, Parties are to specify in domestic access measures how to apply for PIC. ${ }^{165}$ This includes clarifying which national authorities ${ }^{166}$ are empowered to grant PIC, which specific requirements should be fulfilled to apply for PIC (such as details on the application format and content) and specific procedures to be followed. ${ }^{167}$ These minimum requirements should be read in conjunction with other Protocol provisions requiring Parties to provide general and specific information, namely: the obligation to submit information about domestic ABS frameworks, national focal point and competent national authority or

to objectively verifiable circumstances); measures that are based on discretion, prejudice or personal preference, or measures based on pretext: Christoph Schreuer, "Protection against Arbitrary or Discriminatory Measures," in The Future of Investment Arbitration, ed. Catherine A. Rogers and Roger P. Alford (Oxford: Oxford University Press, 2009), 183, 188.

163 Viñuales, Foreign Investment and the Environment, op. cit., 205-206.

164 Ibid., 215.

165 Nagoya Protocol Article 6(3)(c).

166 See this commentary on Article 13, section 3.

167 Greiber et al., Explanatory Guide, op. cit., 104. 
authorities to the ABS Clearinghouse; ${ }^{168}$ the obligation for national ABS focal points to make information on procedures for obtaining PIC and establishing MAT available to applicants seeking access to genetic resources; ${ }^{169}$ and the responsibility of competent national authorities to advise on applicable procedures and requirements for obtaining PIC. ${ }^{170}$

The second minimum requirement calls for providing a clear and transparent written ${ }^{171}$ decision on PIC ${ }^{172}$ by the competent national authority, in a cost effective manner and within a reasonable period of time. ${ }^{173}$ Notably, the Protocol does not set itself specific time limits for domestic access decisionmaking, ${ }^{174}$ but rather leaves discretion to Parties in striking a balance between the interests of users and providers, taking into account the specific circumstances and capacities of relevant authorities. What is considered 'reasonable' may also vary depending on the complexity of the access request, and should be understood in connection with the fair and transparent standards enshrined in Article 6(3)(a-b). There is therefore no expectation that the Protocol will lead to uniform national practices in this regard. ${ }^{175}$ The provision basically seeks to prevent unreliable/unpredictable decision-making on access and to reduce transaction costs, with a view to reasonably meet users' expectations. ${ }^{176}$

The third requirement for domestic access measures is to provide for the issuance at the time of access of a permit or its equivalent, ${ }^{177}$ as evidence of the decision to grant PIC and of the establishment of MAT, and notify ${ }^{178}$ the ABS Clearinghouse accordingly. ${ }^{179}$ This complements the previous requirement,

168 Nagoya Protocol Article 14(2)(a-b). See this commentary on Article 14, section 3.

169 Nagoya Protocol Article 13(1)(a). See this commentary on Article 13, section 2.

170 Nagoya Protocol Article 13(2). See this commentary on Article 13, section 3.

171 Note that the reference to the 'written decision' on access should be read in conjunction with the Protocol provision on national competent authorities 'issuing written evidence that access requirements have been met': Nagoya Protocol Article 13(2).

172 Based on a combined reading with Article 6(3)(c) and (e): Greiber et al., Explanatory Guide, op. cit., 104.

173 Nagoya Protocol Article 6(3)(d).

174 Compare with Biosafety Protocol Article 10.

175 Greiber et al., Explanatory Guide, op. cit., 104.

176 Ibid., 104.

177 Article 6(3)(3). On the meaning of 'its equivalent,' see this commentary on Article 14, section 4.

178 Note that this provision may create some interpretative difficulties when read in conjunction with the other Protocol provisions on the internationally recognized certificate of compliance. See this commentary on Article 17, section 3, and Young, "An International Cooperation Perspective," op. cit., 470.

179 Nagoya Protocol Article 6(3)(e). 
which basically requires the creation in domestic ABS frameworks of a legal basis for domestic decision-making on granting PIC by competent national authorities. The third requirement instead addresses the necessary evidence of such decisions with a view to facilitating implementation of the Protocol's compliance obligations ${ }^{180}$ and protecting the interests of those acquiring genetic resources and of subsequent users. The third requirement must therefore be read in conjunction with other Protocol provisions concerning the internationally recognized certificate of compliance, ${ }^{181}$ as well as on the possibility for competent national authorities to issue either a permit or 'its equivalent.'182

An interpretative problem may arise with reference to 'the time of access', as there is no definition of 'access' in the Nagoya Protocol or the CвD. Nevertheless, as discussed above, ${ }^{183}$ access can occur at the time of different activities in the jurisdiction of the Party providing genetic resources both from in situ or ex situ sources that led to their 'utilization'184 in another Party's jurisdiction. From a practical perspective, it has also been noted that it is at the point of utilization, rather than at the time of access, that actual or potential value of genetic resources becomes evident and more easily verifiable. ${ }^{185}$ So the time of access may be too early to decide what is fair and equitable benefit-sharing. ${ }^{186}$ This may be particularly relevant as negotiations on MAT may precede the issuance of PIC. Ultimately, the uncertainty at the time of access about the actual or potential value of genetic resources may be addressed by a clause in MAT requiring parties to re-negotiate benefit-sharing at the time of utilization. ${ }^{187}$

The fourth requirement concerns the inclusion in domestic access measures of criteria and processes for obtaining PIC or approval and involvement of indigenous and local communities for access to genetic resources held by them, ${ }^{188}$ for Parties on the territory of which these communities hold genetic resources ('where applicable'). In other words, Parties are under an obligation to provide potential users of genetic resources with information on how to apply for community PIC when indigenous and local communities have

\footnotetext{
180 See this commentary on Article 15.

181 Nagoya Protocol Article 17(2-4).

182 Nagoya Protocol Article 13(2).

183 See section 3 above.

184 Nagoya Protocol Article 2(c).

185 Tvedt, "Beyond Nagoya," op. cit., 160.

186 Ibid., 163.

187 See this commentary on Article 5, section 2.

188 Nagoya Protocol Article 6(3)(f).
} 
established rights to grant access to their genetic resources. ${ }^{189}$ This complements the obligation for Parties to establish domestic measures on community PIC for genetic resources held by indigenous and local communities. ${ }^{190}$ The reference to 'accordance with domestic legislation' seems to indicate here that criteria and processes for obtaining community PIC will likely vary from one Party to another. As for other community-related provisions of the Protocol, this requirement should be implemented by taking into consideration the customary laws, protocols and procedures of indigenous and local communities, ${ }^{191}$ and with their effective participation. ${ }^{192}$ It should also be interpreted and implemented in the light of other relevant international human rights obligations and standards. ${ }^{193}$

Minimum Requirements for MAT

The final portion of Article 6(3)(g) sets out minimum requirements on establishing MAT, to be included in domestic access measures: it therefore requires Parties to specify at least some 'clear' rules and procedures for requiring and establishing MAT. ${ }^{194}$ In effect, this is a critical provision, because besides requiring that MAT be established in writing, Article 6(3)(g) contains one of the very few sources of substantive guidance on the establishment of MAT under the Protocol. ${ }^{195}$ That being said, Article 6(3)(g) only contains a non-exhaustive and non-prescriptive list of minimum requirements on the content of мАт. ${ }^{196}$ Parties therefore have discretion to decide to what extent to determine the minimum content of MAT in their domestic ABs frameworks.

189 This complements the obligation under Nagoya Protocol Article 12(2) and in line with relevant international human rights law: see section 4.2.2 above. On established rights, see section 4.1 above.

190 Nagoya Protocol Article 6(2). See also Article 13(1)(b).

191 Nagoya Protocol Article 12(1). See this commentary on Article 12, section 2.

192 UNDRIP Article 19 and 32(2); ILO Convention No. 169, Article 6(2).

193 See Introduction to this commentary, section 4.

194 Nagoya Protocol Article 6(3)(g).

195 The only other provision of the Protocol detailing the establishment of MAT is Article 18(1), whereas the remaining provisions in Article 18 refer to ensuring compliance with мAт: see this commentary on Article 18. See also the obligation for Parties to encourage users and providers to include provisions facilitating monitoring of the utilization of genetic resources in MAT in Nagoya Protocol Article 17(1)(b) and this commentary on Article 17.

196 As appears evident from the use of the terms 'may include, inter alia'. Along the same lines, Greiber et al., Explanatory Guide, op. cit., 106. 
In a light-touch manner, therefore, the Protocol 'promotes best practice in contractual drafting with the aim of protecting the provider of genetic resources.' ${ }^{197}$ This minimalist approach, however, may be criticized in light of experience accrued in ABS transactions occurred prior to the negotiations of the Protocol, which demonstrated that MAT 'are the most complex and controversial elements of ABS practice.'198 The same commentator also underscores that there are few, if any, national ABs measures that regulate the establishment of MAT in a manner that guarantees enforceability; and that therefore international guidance on this matter is necessary. ${ }^{199}$

Specifically, the Protocol limits itself to suggesting that the minimum content of $\mathrm{MAT}^{200}$ be specified in domestic access measures to include, but not be limited to: a dispute settlement clause, the details of which are further elaborated elsewhere in the Protocol;201 terms on benefit-sharing including IPRs; terms of subsequent third-party use; and terms on change of intent, which may be particularly relevant when access is sought to conduct noncommercial research. ${ }^{202}$ As to the latter two instances, the Protocol acknowledges that ABS transactions often involve a chain of providers and users and underscores the need to address in contractual terms whether and which MAT are to apply to subsequent users. That can be the case of genetic resources utilized by the initial user for non-commercial purposes and then utilized by a subsequent user for commercial purposes, in which case 'MAT could include a requirement either for the initial user or the third-party user to first seek the PIC of the initial provider. ${ }^{203}$ It can also be the case of the same user changing his/her intent, in which case 'MAT could provide a requirement to seek [anew] the PIC of the provider country to use the same genetic resources for a new purpose. 204 The reference to IPRs is particularly noteworthy. It has been argued that Article 6(3)(g) serves to recall that the sharing of benefits arising

197 Glowka and Normand, "The Nagoya Protocol on Access and Benefit-sharing," op. cit., 30.

198 Young, “An International Cooperation Perspective," op. cit., 500.

199 Ibid. Such guidance could arguably be provided by the Protocol's governing body at a future stage, in the context of its review of the effectiveness of the international obligations concerning compliance with MAT: Nagoya Protocol Article 18(3).

200 For an indication of possible specific items to be included in domestic access measures in this regard, see Greiber et al., Explanatory Guide, op. cit., 106-107.

201 Nagoya Protocol Article 18(1).

202 Nagoya Protocol Article 8(a). See this commentary on Article 8, section 2.

203 Glowka and Normand, "The Nagoya Protocol on Access and Benefit-sharing," op. cit., 31.

204 Ibid., 31. 
from IPRs should explicitly be addressed through MAT, ${ }^{205}$ because the Protocol itself 'does not impose IP Rs-related benefit-sharing.'206

Based on domestic experience predating the Nagoya Protocol, it has been observed that the crucial matter is to ensure that domestic access frameworks create the right system of incentives for private and public entities to engage in legal ABs transactions and share benefits. ${ }^{207}$ For this reason, the Protocol also foresees that inspiration may be drawn from pre-existing and ongoing practice, including through the use of model contractual clauses and voluntary instruments. ${ }^{208}$ Furthermore, as the Protocol specifically provides for legal recourse in user countries for ensuring users' compliance with MAT (but not with PIC), ${ }^{209}$ it has been argued that Parties would be well advised to set conditions for access in MAT as much as in the decision on PIC, so as to maximize the chance of enforcing any conditions set in PIC. ${ }^{210}$ Finally, it should be anticipated that the Protocol envisages that Parties support indigenous and local communities in their determination of minimum requirements for MAT with specific regard to benefit-sharing from the use of traditional knowledge. ${ }^{211}$

\footnotetext{
205 Ibid., 30.

206 Pavoni, "The Nagoya Protocol and wто," op. cit., 202, emphasis in the original, and his discussion on potential incompatibility with WTO law at 203.

207 Tvedt, "Beyond Nagoya," op. cit., 160-161.

208 See this commentary on Articles 19-20.

209 As compliance with MAT can rely on existing rules of private international law: see this commentary on Article 18.

210 Tvedt, "Beyond Nagoya," op. cit., 172-173.

211 Nagoya Protocol Article 12(3)(b).
} 